\title{
Discussion on Rapid Internationalization Growth Model of Chinese Enterprises
}

\author{
Cuiping $\mathrm{Hu}$ \\ School of Business \\ Huanghe Science and Technology College \\ Zhengzhou, China 450063
}

\author{
Bin Zhang \\ International School \\ Huanghe Science and Technology College \\ Zhengzhou, China, 450063
}

\begin{abstract}
This article researches the phenomenon that Chinese enterprises rapidly become global industry leader in international competition, summarizes four models of rapid internalization of Chinese enterprises: make use of selfindependent innovation to rapidly occupy the market, merger and acquire the world's leading companies in the industry, extend to high value-added stages of global value chain and born globalization. Then it points out main factors that promote internalization of enterprises, hereby puts forward implementation points to promote Chinese enterprises to realize rapid internalization.
\end{abstract}

Keywords $\longrightarrow$ rapid internalization; cross-border mergers and acquisitions; self-independent innovation; global value chain

\section{INTRODUCTION}

Traditional internalization theory based on "competitive advantage" diffusion thinks that only enterprises with relative competitive advantages can carry out internalized operation in other countries. Although researches on emerging economies and internalization of enterprises in developing countries deny it, it mainly researches on the basis of resource exploration or purposes of resource acquisition (Makino, 2002) and defines internationalizing late-coming enterprises as "learners" (Jin Hongping, Wang Zengtao, Zhu Yaling, 2015). However, as late-comers in international competition, Chinese enterprises can become global leader in many industries within a dozen years, with rapid promotion of degree of internalization and acceleration of internalization process. It is necessary for us to research strong internalization development of Chinese enterprises, discuss growth pattern of their rapid internalization and strengthen applicability of situation of existing theory of internationalization, in order to provide references for international operation of other enterprises in China.

\section{GENERAL SITUATION OF INTERNATIONALIZATION DEVELOPMENT OF CHINESE ENTERPRISES}

Before the reform and opening-up policy, Chinese enterprises had few internationalization activities. At the beginning of reform and opening-up policy, it focused on inward internationalization and energetically introduced foreign investment. After the 1990s, Chinese enterprises begin extroverted internationalization that focuses on export. With vigorous promotion of export competitiveness of Chinese products, many countries use barriers such as customs duties, anti-dumping and anti-subsidy to restrict export of Chinese products. Therefore, under the guidance of national policies, enterprises with certain international foundation and development strategy begin outward foreign direct investment. Especially since accessing to the WTO, China's outward foreign direct investment grows greatly and ranks the third place in the world in three years continuously. Besides, activities of outward foreign direct investment also rapidly turn to developed countries and accelerate technology accumulation and innovation, which also promote their technological innovation and industrial upgrading as well as improve international competitiveness. Chinese enterprises also change the past pattern that introduces technology and innovation idea of management first and then improves them and they become more and more internationalized and catch up with and surpass in industries and become industry leaders, such as Sany Heavy Industry, Zoomlion Heavy Industry, Huawei, ZTE, Alibaba and China's railway equipment manufacturing enterprises. These enterprises have faster internationalization speed and higher degree of internationalization. Their development models are not the same. It can provide references for related enterprises through research.

\section{MAIN MODELS OF RAPID INTERNATIONALIZATION OF CHINESE ENTERPRISES}

Enterprise internationalization is the process of international operation of enterprises. The speed or degree of this process influences sustainability of its internationalization behavior. Stage theory of enterprise internationalization namely Uppsala model analyzes stage and models of internationalization (Johanson \&Vahlne, 1977). They think internationalization of enterprises is the process of gradual development and deepening from low degree of difficulty to high degree of difficulty. With emergence of born globalization and rapid internationalization, scholars of this school think interaction of business partners in relationship network of enterprises forms specific network experience and knowledge, and they can get heterogeneous resources and ability of their partners. The speed of organizational learning and internationalization accelerates. The theory finally forms the model of internationalization process (Vahlne \& Ivarsson, 2014). It thinks that in the process of internationalization, mutual commitment with other enterprises makes enterprises rapidly get the ability of internationalization and promotes the "acceleration" of internationalization. The rapid 
internationalization of Chinese enterprises is also the process to rapidly acquire global competitiveness through many ways.

\section{A. Use Self-independent Innovation to Rapidly Occupy the Market}

In high-tech field such as communication equipment, technological competitiveness decides status of international competition, so leading enterprises in the industry block their core technology and don't transfer their technology very often or the transfer cost is high. It is necessary for late-coming enterprises to rapidly improve technical capacity according to self-independent innovation. Huawei and ZTE rely on domestic relatively cheap labor force to aim at the development of peripheral equipment that is neglected by leading enterprises and has large scale of market application, focus on reducing cost of products and rapidly occupy the market to gain rapid growth of scale and profit through lowcost strategy and then turn to field of core technology and market in developed countries. On selection of international market, they firstly choose the market neglected by leaders of international communication equipment, avoid direct competition and extend to North American and European markets via Russia, Southeast Asia, the Middle East, Africa and South America. The experience in internationalization and technical capital accumulated in these developing countries make Huawei and ZTE have the strength to directly compete with international transnational corporations and change from suppliers of low-end device to providers of high-end service, products and solutions. The research and development intensities of Huawei and ZTE reach up to above 10 percent. They set up production, research and development centers distributed in the world. Huawei adopts "pressure tactics" to focus on research and development of cutting-edge core technology. ZTE insists on "patent portfolio" matched with the development of the company. Technical advantages brought by self-independent innovation make enterprises directly compete with enterprises in developed countries, carry out operation in developed countries and rapidly occupy global market.

\section{B. Merger and Acquire Global Leading Enterprises in the Industry}

Although there are many greenbelt investment forms in outward foreign direct investment behaviors of Chinese enterprises, more enterprises directly obtain created assets required by them through merging and acquiring global leading enterprises in the industry, such as brand, marketing channel, patented technology and management mode of company of the other party. Overseas acquisition is the effective way for enterprises in developing countries to acquire strategic assets and improve international competitiveness (Deng, 2009), but the success or failure of merger and acquisition depends on integration after the merger and acquisition and whether they can absorb and make use of resources obtained by them. After the merger and acquisition, use leverage effect of resources to combine resources of different sources through organizational learning and produce competitive advantage (Mathews, 2002). The effect relies on learning ability and absorbing ability of enterprises of merger and acquisition and technological distance between them and target enterprises. Chinese enterprises accumulate sufficient capitals through meeting enormous requirements of domestic market and have carried out cooperation with international leading enterprises in the fields of research and development and production during the period of domestic competition. They know each other well. Target companies don't have big inimical emotion toward Chinese enterprises, which help the rapid integration after merger and acquisition. It is an important way for manufacturing industry of China to realize rapid internationalization through merging and acquiring leading enterprises and replacing them.

\section{Extend to High Value-added Stages of Global Value Chain}

The internationalization of infrastructure construction enterprises in China is accompanied by policy behaviors of the government. From economic aiding diplomacy to economic diplomacy, industries in our country such as equipment manufacture industry, communication and transportation and electricity have become key points of contracted engineering projects for other countries. When government leaders visit foreign countries, they also make an utmost effort to drive or promote these engineering companies to undertake the project in the forms of providing assistance in construction. The profit acquired by internationalization that relies on government promotion and cost advantages is limited, and the promotion of internationalization experience in management mode, information construction and service is slow. After enterprises get familiar with international operation environment, enterprises begin the internationalization operation mode in various forms such as export of labor service, transfer of technology and overall contract and make use of technology and service advantage to carry out high-added engineering design service. When economic interest is improved, the course of internationalization is also accelerated. The industry of engineering construction cannot aim at certain international cooperation project, but know international standard and practical situation of our country through cooperation, focus on world's leading key technology and equipment, in order to acquire overall project instead of construction project in links of low value. The transformation from exporting products or construction with low added value to integrated projects with high added value promotes the acceleration of internationalization of related industries and reinforcement of degree of internationalization.

\section{D. “Born Globalization” of Middle and Small-sized Enterprises}

In recent years, many enterprises have started to carry out internationalized operation since establishment. Even international operation revenue becomes the main source of revenue of enterprises. With high degree of internationalization, they are called "born globalization" enterprises (Oviatt \& McDougall, 1994). The purpose of internationalization has been obvious since the establishment. Entrepreneurs have international perspective and often make use of leading margin technology to produce more increment of value for products to serve niche market. The successful operation of Chinese enterprises of born globalization requires the support from rich enterprises or relationship network of 
entrepreneurs, products with high added value, strong learning ability and absorbing ability as well as active innovation activity (Du Qunyang, Zheng Xiaobi, 2015). Enterprises of born globalization in China are mainly traditional laborintensive manufacturing enterprises. They have low production and administration cost, operate flexibly and are good at imitating, can rapidly occupy international market by relying on industrial cluster superiority and provide professional products and services for a certain country or a few countries. Since the establishment, Henan Rebecca Hair Products, INC has regarded "bringing marvelous beauty for women in the world" as the only mission. It is a professional company of hair products that integrates manufacture, development, production and sale. Over the years, its overseas income occupies 90 percent of the total income of the company. Because these enterprises have small scale, it is easy for them to form and centralize advantages of low cost or professional characteristics. They are easy to become popular in specific markets in the world.

\section{FACTORS TO PROMOTE RAPID INTERNATIONALIZATION OF CHINESE ENTERPRISES}

\section{A. Low Cost}

In the process of internationalization of Chinese enterprises, low cost is often the key to rapidly open international market. Chinese enterprises rely on advantages such as low labor cost, industrial agglomeration and imitative innovation to make products have relative cost advantage on international market. Low cost advantage can rapidly bring profit for enterprises, but for enterprises that carry out international operation for a long time, it is easy for them to fall into "low cost trap". In order to acquire sustaining growth in internationalization, they need to excavate other links of industrial value chain to make profit and transfer to links of high added value. The maintenance of cost advantage also needs enterprises to unceasingly innovate in products and technology according to the change of market demand.

\section{B. Organize Network Learning}

After enterprises carry out international operation, they need to continuously learn operation and management experience of international cooperative partners and local knowledge. Network and economic globalization greatly change competition pattern of enterprises. The acceleration and diffusion of enterprise technology innovation increase pressure of competition of enterprises. The model of traditional individual competition between enterprises is gradually replaced by the model of group alliance competition between enterprises. It appears the "new competition" pattern that integrates competition and cooperation. Enterprises rapidly acquire and share network knowledge and resources with the help of network relationship through establishing formal or informal cooperative relationship with other enterprises and organizations and integrate them with inner resources of enterprise to become basic driving force of rapid growth of enterprises. For enterprises of born globalization, global perspective and international strategic objectives required before or at the beginning of entrepreneurship are often the results achieved by learning from international organizations.

\section{Self-independent Innovation}

No matter relying on advantages of cost or characteristics to open international market, in order to acquire long-term international competitive advantages, enterprises need to rely on continuous innovation of their own. Self-independent innovation also helps to promote absorbing ability for organizational learning. In international competition, they need to face competitors around the world and have more advanced technology. In order to make use of competitive advantage to make profit in global range, transnational corporations often will realize internalized operation or protection of the most advanced technology instead of external transition. It is very difficult for late-coming enterprises to obtain their core leading technology or key technology. Therefore, as latecomers, enterprises also need to continuously carry out selfindependent innovation, in order to survive in international competition for a long time.

\section{Acquire Creative Assets}

In the present international competition, creative assets that take knowledge as the main characteristics become the key for enterprises to improve international competitiveness. The rapid growth of late-coming enterprises needs to acquire knowledge resources and creative assets applicable for the whole world. Besides, the distribution of knowledge resources is imbalanced and focuses on local overflow, as late-coming enterprises, Chinese enterprises need to get close to headstream of advanced technology and knowledge. Although Greenland investment can make use of local professional talents and learn management experience, cross-border mergers and acquisitions can obtain creative assets of target enterprises such as technology, patent, brand and marketing network more rapidly. Therefore, for cross-border mergers and acquisitions, especially merger and acquisition of global leading enterprises in developed countries, it is a shortcut for enterprises to realize rapid internationalization growth and acquire sustaining competitiveness through acquiring creative assets rapidly.

\section{KEY POINTS FOR CHINESE ENTERPRISES TO RAPIDLY IMPLEMENT INTERNATIONALIZATION}

Although Chinese enterprises have a late start in carrying out internationalized operation, and on the basis of lacking competitive advantage, many enterprises realize rapid development of internationalization speed and degree of internationalization. More enterprises need to refer to its development mode to promote rapid development of them in international competition.

Firstly, it is necessary to have clear international perspective and strategic positioning, hereby make use of government policy support or domestic accumulated cost advantage to rapid enter the market in other countries. It requires enterprises to have a clear understanding for competition in international market and market demand by making use of entrepreneurs or international relationship network of enterprise before carrying out international 
operation. Because China has huge market, enterprises can take advantage of technology formed by market demand orientation when they operate in our country or cost advantage to extend to international market. Secondly, when carrying out international operation, they shall attach importance to cooperation with local enterprises and other transnational enterprises, rapidly improve experience in international operation through organizing network learning and pay special attention to setting up research and development organization or marketing channel in local place, accumulate experience to raise the position in global value chain, in order to avoid falling into the trap of internationalization with low added value. Resources such as creative assets and leading technology in the industry are often produced in developed countries with fierce competition. Operating in those places helps to rapidly get familiar with these resources and integrate them in local enterprise network. For creative assets that are difficult for them to acquire rapidly through organizational learning, under the permission of funds, it can be acquired rapidly through merger and acquisition especially for leading enterprises. Finally, no matter adopting what kind of internationalization, enterprises need to improve their technology innovation especially the capability of selfindependent innovation. Self-independent innovation can not only strengthen the sensibility to acquire leading and key technology in the industry, but also improve ability to absorb knowledge and promote learning effects. In addition, in face of blockade on techniques of leading enterprises, it is the only way that can realize technology leapfrogging.

\section{REFERENCES}

[1] Deng P. Why do Chinese Firms Tend to Acquire Strategic Assets in International Expansion? [J]. Journal of World Business, 2009, 44(1): $74-84$.

[2] Johanson J, Vahlne J. The Internationalization Process of the Firm-A Model of Knowledge Development and Increasing Foreign Market Commitments[J]. Journal of International Business Studies, 1977, 8(1): 23-32.

[3] Makino S, Lau C M, Yeh R S. Asset-exploitation versus asset-seeking: Implications for location choice of foreign direct investment from newly industrialized economies[J]. Journal of International Business Studies, 2002, 33(3): 403-421.

[4] Mathews J A, Competitive Advantage of the Latercomer Firms:A Resourcebased Account of Industial Catch-Up Strategies.Asia Pacific Journal ofManagement, 19, 2002.

[5] Vahlne J E, Ivarsson I. The Globalization of Swedish MNEs: Empirical Evidence and Theoretical Explanations[J]. Journal of International Business Studies, 2014, 45(3): 227-247.

[6] Du Qunyang, Zheng Xiaobi. International Entrepreneurial Orientation of Born Global Enterprises and Internationalization Performance-on the Basis of Perspective of Dynamic Coupling between Network Relation and Learning Orientation.

[7] Jin Hongping, Wang Zengtao, Zhu Yaling. Organizational Learning in Internalization: Two-dimensional Perspective of One Scope and Way [J], Science and Technology Management Research, 2015, 35(18): 208212. 